\title{
Adverse Effects of Monosodium Glutamate on Liver and Kidney Functions in Adult Rats and Potential Protective Effect of Vitamins $\mathbf{C}$ and $\mathbf{E}$
}

\author{
Manal Said Tawfik ${ }^{*}$, Nawal Al-Badr ${ }^{2}$ \\ ${ }^{1}$ Department of Food Science and Technology, Faculty of Agriculture-El-Shatby, Alexandria University, Alexandria, Egypt; \\ ${ }^{2}$ Department of Food Nutrition, King Saud University, Riyadh, Saudi Arabia. \\ Email: ${ }^{*}$ mana92t@yahoo.com
}

Received February $18^{\text {th }}, 2012$; revised March $16^{\text {th }}, 2012$; accepted March $23^{\text {rd }}, 2012$

\begin{abstract}
Monosodium glutamate (MSG) was administrated to rats at doses of 0.6 and $1.6 \mathrm{mg} / \mathrm{g}$ body weight for 14 days. Body weight and relative liver and kidney weight of rats were significantly increased. On regard to liver functions, the activities of alanine aminotransferase (ALT) and $\gamma$ glutamyle transferase (GGT) significantly increased in the serum, on MSG administration, meanwhile, serum total protein, albumin and serum total bilirubin significantly decreased. MSG had adverse effects on kidney functions as serum urea and serum creatinine were significantly increased. Vitamin $C(0.3$ $\mathrm{mg} / \mathrm{g}$ body weight) and vitamin $\mathrm{E}(0.2 \mathrm{mg} / \mathrm{g}$ body weight) co-adminstrated with MSG, significantly restored the body weight and relative liver and kidney weights to control levels. In the presence of vitamin $\mathrm{C}$ and vitamin $\mathrm{E}$ the activities of ALT and GGT in the serum were also significantly reduced to become comparable with control trail. Consequently, serum total protein, albumin and serum total bilirubin were significantly increased in the serum, while serum urea and serum creatinine were significantly decreased after administration of each vitamin. The results showed that MSG at doses of 0.6 and $1.6 \mathrm{mg} / \mathrm{g}$ of body weight may cause an adverse effect on the hepatic and renal functions which might be due to oxidative stress induced by MSG on the liver and renal tissue. Supplementation of vitamin C and vitamin E was capable of ameliorating MSG-induced oxidative stress on hepatic and renal functions.
\end{abstract}

Keywords: Monosodium Glutamate; Hepatic Stress; Renal Stress; Alanine Aminotransferase; $\gamma$ Glutamyle Transferase; Creatinine; Total Bilirubin

\section{Introduction}

Monosodium glutamate (MSG) known as AJI-NOMOTO is the sodium salt of glutamic acid [1]. MSG contains $78 \%$ of glutamic acid, $22 \%$ of sodium and water [2]. Glutamate is one of the most common amino acids found in nature and is the main component of many proteins and peptides of most tissues. Glutamate is also produced in the body and plays an essential role in human metabolism. It is a major component of many protein-rich food products either in free or bound state of animal such as meat, fish, milk and cheese or vegetable origins such as mushroom and tomato [3]. MSG is commonly used as a flavor enhancer especially in Chinese, Thainese and Japanese foods $[4,5]$.

When MSG is added to food, it provides a flavoring function similar to the naturally occurring free glutamate which differ from the four classic tastes of sweet, sour, salty and bitter [6]. As food additive, MSG is described

\footnotetext{
${ }^{*}$ Corresponding author.
}

and listed on food labels as a "Flavoring" or "hydrolysed vegetable protein". Through its stimulation of the orosensory receptors and by improving the palatability of meals, MSG influences the appetite positively, and induces weight gain. Despite its taste stimulation and improved appetite enhancement, reports indicate that MSG is toxic to human and experimental animals [7]. MSG could produce symptoms such as numbness, weakness, flushing, sweating, dizziness and headaches. In addition to these MSG symptom complex, ingestion of MSG has been alleged to cause or exacerbate numerous conditions, including asthma, urticaria, atopic dermatitis, ventricular arrhythmia, neuropathy and abdominal discomfort [8].

MSG has a toxic effect on the testis by causing a significant oligozoospermia and increase abnormal sperm morphology in a dose-dependent fashion in male Wistar rats [9]. It has been implicated in male infertility by causing testicular hemorrhage, degeneration and alteration of sperm cell population and morphology [10]. It has been reported that MSG has neurotoxic effects resulting 
in brain cell damage, retinal degeneration, endocrine disorder and some pathological conditions such as addiction, stroke, epilepsy, brain trauma, neuropathic pain, schizophrenia, anxiety, depression, Parkinson's disease, Alzheimer's disease, Huntington's disease, and amyotrophic lateral sclerosis [2]. It cannot be stated that MSG is the cause of such varied conditions as epilepsy and Alzheimer's disease, although there may be concerns of its involvement in its etiology [2].

The Food and Drug Administration (FDA) of the United States reports that MSG is safe and that it should be maintained on the "Generally Recognized as Safe" (GRAS)-list of foods. MSG is thus reportedly permitted as a safe food additive that needs no specified average, daily intake or an upper limit intake requirement [11].

Liver is the largest gland in the mammalian body. The hepatocytes have metabolic functions that deal with very essential processes such as detoxification, deamination, transamination, removal of ammonia in the form of urea, biosynthesis and release of the non-essential amino acids and plasma proteins with the exception of immuno gamma globulins, gluconeogenesis, storage of glycogen, conversion of carbohydrates and proteins into lipids, synthesis of lipoproteins, phospholipids and cholesterol, oxidation of fatty acids, storage of iron in the form of ferritin as well as storage of vitamins A, D and B12. Several functional tests have been formulated to explore hepatic status [12-16]. Several enzymes have been determined to explore hepatic status such as alanine amino transferase (ALT) and aspartate amino transferase (AST). In addition some other tests include measurement of serum lactic dehydrogenase (LDH), gamma glutamyl transpeptidase (GGT), alkaline phosphatases and 5-nucleotidase activities are employed [17-19].

The Kidney is a paired organ located in the posterior abdominal wall, whose major functions include the removal of toxic metabolites and waste products from the blood and regulation of the amount of fluid and electrolytes balance in the body. To test functions of the kidneys routine urinalysis is used to measure serum urea, creatinine, sodium and potassium and serum bicarbonate [13,18-20].

Vitamins have indispensable role in almost all biochemical reactions and they are ideal antioxidants able to increase tissue protection from oxidative stress due to their easy, effective and safe dietary administration in a large range of concentrations [21,22]. Vitamin E $(\alpha-$ Tocopherol $[(\alpha-$ Toc $])$ is the primary membrane bound, lipid-soluble, chain-breaking antioxidant that protects cell membranes against lipid peroxidation [23-26].

Vitamin E pre-treatment has been reported to be beneficial in preventing formaldehyde-induced tissue damage in rats $[24,27]$. The preventive effect of vitamin $\mathrm{E}$ on cypermethrin or endotoxin-induced oxidative stress in rat tissues is suggestive of its antioxidant activity [2833].

L-ascorbic acid is the first to become depleted on the exposure to oxidative stress [34]. Normal L-ascorbate level has a therapeutic benefit due to its ability to reduce the oxidative stress by reacting with superoxide and hydroxide radicals as well as alkyl, peroxyl and alkoxyl radicals, thereby it can neutralize these radicals and stop the initiation and propagation of chain reaction $[35,36]$.

Although some information is available on the MSGinduced oxidative stress and toxicity, the studies on the effect antioxidants, especially those consumed in food on MSG-induced toxicity and oxidative stress are lacking. Moreover, most of studies, so far on MSG, have been carried out on very high doses $(4 \mathrm{mg} / \mathrm{g}$ and above) except of the study of Onyema et al., 2006 [37]. Thus, There is need to substantiate whether MSG induce oxidative stress at an appreciably lower doses and study the effect of nutritional antioxidants on it.

The objective of this research was designed to study the effect of MSG at two oral low doses of 0.6 and 1.6 $\mathrm{mg} / \mathrm{g}$ body wt on liver and kidney functions in albino rats. The possible protective effect of vitamin $\mathrm{E}$ (at oral dose of $0.2 \mathrm{mg} / \mathrm{g}$ body wt) and vitamin C (at oral dose of 0.3 $\mathrm{mg} / \mathrm{g}$ body wt) against MSG induced hepatic and renal stress was also investigated.

\section{Materials and Methods}

\subsection{Animals}

Adult albino rats of both sex with average weight of $95 \mathrm{~g}$ were obtained from King Saud University Animal Care Center. The animals were housed in cages under standard hygienic condition and were fed with rat chow and water ad labium. In order to optimize treatment doses, all animals were fasted for $1 \mathrm{~h}$ prior to treatment administration.

\subsection{Chemicals}

MSG was purchased from BDH laboratory (Poole, UK), vitamin $\mathrm{C}$ and vitamin $\mathrm{E}$ were obtained from Sigma-Aldrich Chemicals Co. (St. Louis, MO, USA). All chemical reagents were of analytical grades and purchased from Sigma Chemical Co. (St. Louis, MO, USA).

\subsection{Experimental Design}

Animals were randomly assigned into seven groups of ( $\mathrm{n}$ $=8$ ); Group 1 and groups from 2 to 7 served as control and experimental groups respectively. Groups 2 and 3 were given $0.6 \mathrm{mg} / \mathrm{g}$ body weight and $1.6 \mathrm{mg} / \mathrm{g}$ body weight of MSG respectively on a daily basis; groups 4 
and 5 were given $0.6 \mathrm{mg} / \mathrm{g}$ body weight and $1.6 \mathrm{mg} / \mathrm{g}$ body weight of MSG plus $0.3 \mathrm{mg} / \mathrm{g}$ body weight vitamin $\mathrm{C}$ on a daily basis; groups 6 and 7 were given $0.6 \mathrm{mg} / \mathrm{g}$ body weight and $1.6 \mathrm{mg} / \mathrm{g}$ body weight of MSG plus 0.2 $\mathrm{mg} / \mathrm{g}$ body weight vitamin $\mathrm{E}$ on a daily basis. Group 1, received equal amount of feeds without MSG and vitamins added for fourteen days. The rats were sacrificed on the fifteenth day of the experiment. The choice of MSG doses, vitamin $\mathrm{E}$ and $\mathrm{C}$ doses was based on previous reported studies $[37,38]$.

\subsection{Body, Relative Liver and Kidney Weight}

Body weight of each animal was determined before treatments and before sacrifice. Liver and kidneys of each animal were dissected out and weighed.

\subsection{Blood Collection and Separation}

At the end of treatment period the animals were sacrificed $24 \mathrm{hr}$ following the last given dose. Blood samples were withdrawn and collected in glass tubes. Serum was separated by centrifugation at $3000 \mathrm{rpm}$ for $10 \mathrm{~min}$ and stored at $-80^{\circ} \mathrm{C}$ bending biochemical analysis.

\subsection{Biochemical Assays}

\subsubsection{Assessment of Liver Function}

\subsubsection{Alanine Aminotransferase (ALT)}

Alanine aminotransferase catalysed the transfer of an amino group between the amino acids L-alanine and Lglutamate. The ketoacids formed in this process were $\alpha$-ketoglutarate and pyruvate. The pyruvate formed reacted with dinitrophenylhydrazine to produce a corresponding dinitrophenylhydrazone, which was measured with the spectrophotometer at $505 \mathrm{~nm}$ [39].

\subsubsection{Protein}

The peptide bonds of plasma protein in plasma reacted with biuret reagent which contained copper in alkaline solution to form a violet colored which was measured with a spectrophotometer at $540 \mathrm{~nm}$ [40].

\subsubsection{Bilirubin}

Plasma was added to a solution of sodium acetate and caffeine (sodium benzoate) which was then added to diazotized sulfanilic acid to form a purple azo bilirubin. The sodium acetate buffered the $\mathrm{pH}$ of the diazotized sulfanilic acid. The reaction was terminated by the addition of ascorbic acid which destroyed the excess diazo reagent. A strongly alkaline tartrate solution was then added to convert the purple azobilirubin to blue azoblilrubin and the intensity of the color was measured at 600 $\mathrm{nm}$ with a spectrophotometer [39].

\subsubsection{Albumin}

Bromocresol green, a dye at an acid $\mathrm{pH}$ of 3.8 preferentially bound albumin to produce a shade of green color which was measured with a spectrophotometer at $630 \mathrm{~nm}$ [41].

\subsubsection{5. $\gamma$ Glutamyletransferase (GGT)}

For determination of GGT activity, the serum sample was added to a substrate solution containing glycylglycine, $\mathrm{MgCl}_{2}$ and $\gamma$ glutamyle-p-nitroanilide in $0.05 \mathrm{M}$ tris (free base), $\mathrm{pH} 8.2$. The mixture was incubated at $37^{\circ} \mathrm{C}$ for $1 \mathrm{~min}$ interval for $5 \mathrm{~min}$. The activity of GGT was calculated from the absorbance values [37].

\subsubsection{Assessment of Kidney Function}

\subsubsection{Serum Urea}

Urea content of the serum samples was estimated by means of an automated analyzer, Blood Urea Analyzer, Beckman Coulter Inc., USA. The analysis procedure required a set up of reagents, Hichem kit of reagents for blood urea nitrogen analyzer. The kit is supplied by Elan Diagnostics, USA [42].

\subsubsection{Serum Creatinine}

Creatinine Analyzer-2 (Beckman Coulter Inc., USA) in combination with a specific kit of reagents (Hichem Creatine Pak, Elan Diagnostics, USA) were employed to calculate creatinine content of the serum samples [42].

\subsection{Statistical Analysis}

Results obtained from the experiment were analyzed using analysis of variance (ANOVA), while comparisons were made using the Dunnet's test at $\mathrm{P}<0.05$ level of significance.

\section{Results and Discussion}

\subsection{Body Weight}

Comparison of the final body weight with the initial body weight in each group revealed a significant difference and hence the increase of about $34.6 \%, 44.5 \%$ was considerable in group 2 and group 3 respectively (MSG treated animals) compared with an increase of about $31.8 \%$ in Group1 (control) (Table 1). MSG intake could induce an increase in energy intake [43] which could lead to obesity [44] or alter the levels of carbohydrates, lipids and proteins in rats [45].

The controlling of body weight in MSG + V.C treated animals $(31.5 \%, 30.9 \%)$ in group 4 and group 5 and MSG + V.E treated animals $(30.5 \%, 30.2 \%)$ in group 6 and group 7 reflected the possible role of vitamins which 
Table 1. Changes in body, liver and kidneys weights of control and rats treated with mono sodium glutamate (MSG) in the absence and presence of Vitamin C (V.C) or Vitamin E (V.E) expressed in grams ${ }^{1}$.

\begin{tabular}{|c|c|c|c|c|}
\hline Groups & $\begin{array}{l}\text { Initial Body Weight } \\
(\mathrm{g})^{2}\end{array}$ & $\begin{array}{c}\text { Final Body Weight } \\
\text { (g) }\end{array}$ & $\begin{array}{c}\text { Relative Liver Weight } \\
(\mathrm{g} / \mathbf{1 0 0 g})^{2}\end{array}$ & $\begin{array}{c}\text { Relative Kidneys Weight } \\
(\mathrm{g} / \mathbf{1 0 0 g})^{3}\end{array}$ \\
\hline Group1 (Control) & $88 \pm 5.2$ & $116 \pm 6.4$ & $3.65 \pm 0.12^{\mathrm{a}}$ & $0.75 \pm 0.02^{\mathrm{a}}$ \\
\hline Group 2 ( $0.6 \mathrm{mg} / \mathrm{g}$ b.w. MSG) & $101 \pm 2.1$ & $136 \pm 5.3$ & $3.85 \pm 0.17^{\mathrm{b}}$ & $0.78 \pm 0.01^{\mathrm{b}}$ \\
\hline Group 3 (1.6 mg/g b.w. MSG) & $101 \pm 1.3$ & $146 \pm 5.1$ & $4.16 \pm 0.21^{\mathrm{c}}$ & $0.80 \pm 0.01^{\mathrm{c}}$ \\
\hline $\begin{array}{l}\text { Group } 4(0.6 \mathrm{mg} / \mathrm{g} \text { b.w. MSG } \\
+0.3 \mathrm{mg} / \mathrm{g} \text { b.w. V.C })\end{array}$ & $92 \pm 4.7$ & $121 \pm 4.7$ & $3.68 \pm 0.13^{\mathrm{a}}$ & $0.76 \pm 0.01^{\mathrm{a}}$ \\
\hline $\begin{array}{c}\text { Group } 5(1.6 \mathrm{mg} / \mathrm{g} \text { b.w. MSG } \\
+0.3 \mathrm{mg} / \mathrm{g} \text { b.w V.C })\end{array}$ & $94 \pm 3.6$ & $123 \pm 3.9$ & $3.77 \pm 0.09^{\mathrm{d}}$ & $0.70 \pm 0.02^{\mathrm{d}}$ \\
\hline $\begin{array}{l}\text { Group } 6(0.6 \mathrm{mg} / \mathrm{g} \text { b.w. MSG } \\
+0.2 \mathrm{mg} / \mathrm{g} \text { b.w. V.E) }\end{array}$ & $95 \pm 2.7$ & $124 \pm 3.4$ & $3.60 \pm 0.15^{\mathrm{a}}$ & $0.72 \pm 0.03^{\mathrm{a}}$ \\
\hline $\begin{array}{l}\text { Group } 7(1.6 \mathrm{mg} / \mathrm{g} \text { b.w. MSG } \\
\quad+0.2 \mathrm{mg} / \mathrm{g} \text { b.w. V.E })\end{array}$ & $96 \pm 5.1$ & $125 \pm 3.1$ & $3.67 \pm 0.14^{\mathrm{a}}$ & $0.78 \pm 0.04^{\mathrm{a}}$ \\
\hline
\end{tabular}

${ }^{1}$ Mean \pm SD. $\mathrm{N}=8$ for the control; $\mathrm{N}=8$ for treated group; ${ }^{2}$ Mean of the final body weight is compared with that of the initial; ${ }^{3}$ Mean of the relative organ weight in treated group is compared with the corresponding mean of the control. $P$ value of less than 0.05 indicates a significant difference between the compared means.

could lead to change in functions against MSG oxidant effect of the organs that are regulated by the nervous system and metabolic activities [46].

\subsection{Relative Liver and Kidneys Weight}

A significant increase in the liver and kidney weight of the rats was observed after administration of MSG at two employed doses (Table 1). Thus, could be attributed to an increase in activity of inflammatory agents that could have resulted to inflammation of liver and kidney tissues [47].

Vitamin C and Vitamin E reduced the MSG-induced increase in the liver and kidney weight (Table 1), and vitamin $\mathrm{E}$ was more effective especially with higher intake of MSG, possibly via its action as a radical scavenger. By scavenging the radicals that contributed to oxidative stress induced by MSG, Vitamin E could help in reducing inflammation [37]. The changes in relative liver and kidneys weights have been accompanied with changes in functional aspects.

\subsection{Liver Functions}

\subsubsection{Serum Alanine Aminotransferase (ALT)}

Table 2 shows activities of ALT enzyme that were measured in serum samples. Significant $(p<0.05)$ increases in the serum alanine aminotransferase was observed in the MSG-treated rats compared to the control rats (Table 2). Alanine aminotransferase (ALT) had activities means of 32.1, 40.3 and $46.6 \mathrm{U} / \mathrm{L}$ in serum of the control and MSG treated adult rats $(0.6 \mathrm{mg} / \mathrm{g}$ and 1.6 $\mathrm{mg} / \mathrm{g}$ body weight) respectively. The observed increase in activity was around $25.5 \%, 45.2 \%$ in the two doses.
The ALT enzyme is a sensitive marker of liver damage [48]. Therefore, the increase in the serum ALT activity might perhaps be an indication of liver damage. MSG could dissociate easily to release free glutamate. The diminution of GLU produces ammonium ion $\left(\mathrm{NH}_{4}^{+}\right)$that could be toxic unless detoxified in the liver via the reactions of the urea cycle. Thus, the possible ammonium ion overload that may occur as a result of an increased level of glutamate following MSG intake could damage the liver, consequently releasing the ALT enzyme that may lead to its observed elevation. This increase could also be explained by free radical production which reacts with polyunsaturated fatty acids of cell membrane leading to impairment of mitochondrial and plasma membranes resulting in enzyme leakage [49].

The result seemingly agrees with the reports of Farombi and Onyema (2006) and Onyema et al. (2006) [37,50] that the activity of serum ALT increased in male rats that were fed MSG probably due to the finding that MSG induced oxidative stress in the liver. Thus, it could be concluded that MSG may be hepatotoxic at a low dose, hence should be avoided during the treatment of liver disorders. Furthermore, since ALT was a strong positive indicator of insulin resistance, diabetes mellitus and obesity [51] which are risk factors for coronary heart disease [52-54], the use of MSG even at low doses should not be encouraged because of the possible health implications. The serum ALT shows functional activity of liver. An increase in the activities of these enzymes indicates an effect due to the doses.

Administration of V.C and V.E resulted a significant reduction in the serum level of ALT enzyme at both MSG doses (Table 2). The use of V.E found to be more 
Table 2. Liver function indexes of the control and treated adult rats with mono-sodium glutamate (MSG) in the absence and presence of Vitamin C (V.C) or Vitamin E (V.E) ${ }^{1}$.

\begin{tabular}{|c|c|c|c|c|c|}
\hline Groups & $\operatorname{ALT}(\mu / L)$ & $\begin{array}{l}\text { Serum Total Protein } \\
(\mathrm{g} / \mathrm{dl})\end{array}$ & $\begin{array}{l}\text { Serum Total Bilirubin } \\
(\mathrm{mg} / \mathrm{dl})\end{array}$ & Albumin $(g / L)$ & GGT $(\mu / L)$ \\
\hline Group1 (Control) & $32.1 \pm 2.1^{\mathrm{a}}$ & $6.5 \pm 0.1^{\mathrm{a}}$ & $0.68 \pm 0.03^{\mathrm{a}}$ & $31.3 \pm 2.9^{\mathrm{a}}$ & $20.5 \pm 2.2^{\mathrm{a}}$ \\
\hline Group 2 (0.6 mg/g b.w. MSG) & $40.3 \pm 3.5^{\mathrm{b}}$ & $6.1 \pm 0.2^{\mathrm{b}}$ & $0.61 \pm 0.02^{\mathrm{b}}$ & $22.2 \pm 3.1^{\mathrm{b}}$ & $22.1 \pm 1.8^{\mathrm{a}}$ \\
\hline Group 3 (1.6 mg/g b.w. MSG) & $46.6 \pm 1.4^{\mathrm{c}}$ & $5.8 \pm 0.2^{\mathrm{c}}$ & $0.54 \pm 0.02^{\mathrm{c}}$ & $20.6 \pm 4.2^{\mathrm{c}}$ & $24.3 \pm 1.2^{\mathrm{b}}$ \\
\hline $\begin{array}{l}\text { Group } 4(0.6 \mathrm{mg} / \mathrm{g} \text { b.w. MSG } \\
\quad+0.3 \mathrm{mg} / \mathrm{g} \text { b.w. V.C })\end{array}$ & $34.3 \pm 2.8^{\mathrm{a}}$ & $6.4 \pm 0.1^{\mathrm{a}}$ & $0.65 \pm 0.03^{\mathrm{a}}$ & $28.5 \pm 3.4^{\mathrm{a}}$ & $21.2 \pm 2.3^{\mathrm{a}}$ \\
\hline $\begin{array}{c}\text { Group } 5(1.6 \mathrm{mg} / \mathrm{g} \text { b.w. MSG } \\
+0.3 \mathrm{mg} / \mathrm{g} \text { b.w V.C })\end{array}$ & $35.2 \pm 1.2^{\mathrm{d}}$ & $6.1 \pm 0.1^{\mathrm{b}}$ & $0.58 \pm 0.03^{b}$ & $26.2 \pm 2.2^{\mathrm{d}}$ & $22.6 \pm 2.6^{\mathrm{a}}$ \\
\hline $\begin{array}{c}\text { Group } 6(0.6 \mathrm{mg} / \mathrm{g} \text { b.w. MSG } \\
+0.2 \mathrm{mg} / \mathrm{g} \text { b.w. V.E })\end{array}$ & $33.1 \pm 1.9^{\mathrm{a}}$ & $6.4 \pm 0.2^{\mathrm{a}}$ & $0.66 \pm 0.02^{\mathrm{a}}$ & $30.9 \pm 1.7^{\mathrm{a}}$ & $20.3 \pm 1.4^{\mathrm{a}}$ \\
\hline $\begin{array}{c}\text { Group } 7(1.6 \mathrm{mg} / \mathrm{g} \text { b.w. MSG } \\
\quad+0.2 \mathrm{mg} / \mathrm{g} \text { b.w. V.E) }\end{array}$ & $34.2 \pm 2.3^{\text {ad }}$ & $6.1 \pm 0.1^{b}$ & $0.67 \pm 0.01^{\mathrm{a}}$ & $28.4 \pm 3.1^{\mathrm{a}}$ & $21.2 \pm 2.1^{\mathrm{a}}$ \\
\hline
\end{tabular}

$\mathrm{ALT}=$ Alanine Amino Transferase, previously called Glutamate Pyruvate Amino Transferase $(\mathrm{GPT}) . \mathrm{GGT}=\gamma$ glutamyletransferase. Mean \pm SD. $\mathrm{N}=8$ for the control; $\mathrm{n}=8$ for treated group. Mean of treated group is compared with the corresponding mean of the control. $P$ value of less than 0.05 indicates a significant difference between the compared means.

effective in improving in the serum level of ALT enzyme especially with the lower dose of MSG $(0.6 \mathrm{mg} / \mathrm{g}$ body weight). This result agrees with the published studies where pre-treatment with vitamin $\mathrm{E}$ has been reported to confer protection against such changes in monosodium glutamate induced-hepatotoxicity and oxidative stress in rats $[24,37]$.

\subsubsection{Serum Total Protein}

The determined mean value of total protein in serum of control rats was $6.5 \mathrm{~g} / \mathrm{dl}$. Serum samples of treated animals contained total protein whose mean was 6.1 and $5.8 \mathrm{~g} / \mathrm{dl}$. The $6.2 \%$ and $10.8 \%$ reduction in serum total protein of MSG dosed rats $(0.6,1.6 \mathrm{mg} / \mathrm{g}$ b.w.) failed to reach the statistical significance level (Table 2).

Additional of V.E and V.C resulted in a significant improvement in the serum total protein levels of lower MSG dosed rats ( $0.6 \mathrm{mg} / \mathrm{g}$ b.w.) (Table 2). Both vitamins have the ability to prevent oxidative stress which affects liver the main site for protein synthesis in the body.

\subsubsection{Serum Total Bilirubin}

It was found that there was a decrease $(10.3 \%, 20.6 \%)$ in serum total bilirubin treated animals (Table 2). Control animals had a $0.68 \mathrm{mg}$ total bilirubin/dl serum, whereas a mean values of 0.61 and 0.54 was recorded in serum of group 2 and 3 respectively. The difference between the compared groups was statistically significant $(p \leq 0.05)$ (Table 2). Serum total bilirubin were found to be significantly increased in the serum after administration of vitamin $\mathrm{C}$ and vitamin $\mathrm{E}$ with MSG (Table 2).

\subsubsection{Albumin}

Albumin concentration decreased in the serum of MSG dosed rats. Tests performed in MSG-treated rats showed a significant decreased in serum albumin levels when compared to normal control group (Table 2). The synthetic function of liver was altered by MSG, so albumin level decreased. Albumin concentration increased in the serum of MSG administrated by additional of V.C and V.E dosed rats (Table 2).

The concentration of proteins, bilirubin and albumin in the serum can be used as indicators for the state of the liver and can be used to differentiate between different types of liver damage. The observed reduction in albumin and total bilirubin concentrations in serum (Table 2) indicated liver damage [55], arising from the uptake of the chemical compound. This may be an indication of diminished synthetic function of the liver which may consequently lead to enhanced retention of fluid in the tissues spaces [55].

\subsubsection{GGT Activity}

The activities of the serum enzyme markers of hepatocellular injury (GGT) increased significantly by MSG administration at concentration of $1.6 \mathrm{mg} / \mathrm{g}$ body weight. Vitamin $\mathrm{C}$ and Vitamin $\mathrm{E}$ when administrated with MSG reduced the activity of GGT (Table 2).

GGT is also elevated in most cases of liver disorders [56]. Therefore, the increased activity of GGT in the sera of MSG treated animals might have resulted from the liver injury caused by the MSG-induced oxidative stress. A similar trend was observed in the study of Onyema et 
al., 2006 [37] when adding Vitamin E with MSG.

\subsection{Kidney Functions}

\subsubsection{Serum Urea}

Blood serum samples of the rats treated with MSG contained low significant urea nitrogen as compared with urea nitrogen mean values of the control (Table 3). Mean serum urea of the control animals was $35.2 \mathrm{mg} / \mathrm{dl}$ and that of the MSG treated rats were 31.4 and $24.1 \mathrm{mg} / \mathrm{dl}$ of two MSG doses. Urea is the major nitrogen-containing metabolic product of protein catabolism. The significant reduction in serum urea concentration throughout the experimental period may be attributed to impairment of the urea cycle leading to reduced production of the metabolic product.

The serum urea nitrogen is a measure of renal function. Normally, the serum urea nitrogen level rises in heart failure, dehydration, or a high protein diet and low urea nitrogen level can be seen in liver and renal damage or in liver diseases [57].

\subsubsection{Serum Creatinine}

A change in serum creatinine level is also an indicator of kidney function. Therefore, in the present study serum creatinine was determined to find out the effect of MSG on renal functional markers such as serum creatinine, and serum urea nitrogen.

Concentration of creatinine in serum samples of control and treated animals were, respectively, 0.30, 0.44 and $0.54 \mathrm{mg} / \mathrm{dl}$ (Table 3). Serum creatinine of the treated rats was found to be more than that in control serum. The difference between means was significant $(p \leq 0.05)$.

The significant increase in creatinine content of the serum following the administration of MSG may be attributed to compromise of the renal functional capacity. MSG might have either interfered with creatinine metabolism leading to increased synthesis or the tissues might have compromised all or part of its functional capacity of tubular excretion [58-60]. Exposure to MSG may cause an adverse effect on the renal function which might be due to oxidative stress induced by MSG on the renal tissue.

Addition of V.E and V.C resulted in a significant improvement in the serum levels of biochemical parameters in kidneys (Table 3).

Farombli, 2006 [61] has shown that dietary antioxidants such as Vitamin C and Vitamin E has a modulator effects on MSG-induced serum urea oxidative damage in the liver and kidney of rats. The variation in the level of urea and creatinine are markers of renal dysfunction.

\section{Conclusion}

The results of the present investigation have shown that mono-sodium glutamate (MSG) at low doses is capable of producing alterations in the body weight and liver and kidney functions. These alterations appear in the liver and kidney probably because these organs are mainly responsible for detoxification of foreign compounds in the body. Vitamin C and Vitamin E have been shown to protect and restore the liver and kidney capabilities in several models injury via inhibiting oxidative damage

\section{Acknowledgements}

This research project was supported by a grant from the research center of the center for female scientific and

Table 3. Kidney function indexes of the control and treated rats with mono-sodium glutamate (MSG) in the absence and presence of Vitamin C (V.C) or Vitamin E (V.E) ${ }^{1}$.

\begin{tabular}{|c|c|c|}
\hline Groups & Serum Urea (mg/dl) & Serum Creatinine (mg/dl) \\
\hline Group 1 (Control) & $35.2 \pm 1.4^{\mathrm{a}}$ & $0.30 \pm 0.04^{\mathrm{a}}$ \\
\hline Group 2 (0.6 mg/g b.w. MSG) & $31.4 \pm 1.6^{\mathrm{b}}$ & $0.44 \pm 0.05^{\mathrm{b}}$ \\
\hline Group 3 (1.6 mg/g b.w. MSG) & $24.1 \pm 1.8^{\mathrm{c}}$ & $0.54 \pm 0.07^{\mathrm{c}}$ \\
\hline Group $4(0.6 \mathrm{mg} / \mathrm{g}$ b.w. MSG $+0.3 \mathrm{mg} / \mathrm{g}$ b.w. V.C $)$ & $33.3 \pm 1.3^{\mathrm{a}}$ & $0.34 \pm 0.06^{\mathrm{ad}}$ \\
\hline Group 5 (1.6 mg/g b.w. MSG $+0.3 \mathrm{mg} / \mathrm{g}$ b.w. V.C $)$ & $29.3 \pm 2.3^{\mathrm{bd}}$ & $0.38 \pm 0.05^{\mathrm{d}}$ \\
\hline Group $6(0.6 \mathrm{mg} / \mathrm{g}$ b.w. MSG $+0.2 \mathrm{mg} / \mathrm{g}$ b.w. V.E $)$ & $33.8 \pm 1.9^{\mathrm{a}}$ & $0.33 \pm 0.03^{\text {ad }}$ \\
\hline Group 7 (1.6 mg/g b.w. MSG $+0.2 \mathrm{mg} / \mathrm{g}$ b.w. V.E) & $28.6 \pm 1.6^{\mathrm{d}}$ & $0.35 \pm 0.02^{\mathrm{ad}}$ \\
\hline
\end{tabular}

Mean \pm SD. $\mathrm{N}=8$ for the control; $\mathrm{N}=8$ for treated group; Mean of treated group is compared with the corresponding mean of the control. $P$ value of less than 0.05 indicates a significant difference between the compared means. 
medical colleges in King Saud University.

\section{REFERENCES}

[1] A. O. Eweka, "Histological Studies of the Effects of Monosodium Glutamate on the Kidney of Adult Wistar Rats," The Internet Journal of Health, Vol. 6, No. 2, 2007.

[2] A. Samuels, "The Toxicity/Safety of MSG: A Study in Suppression of Information," Accountability in Research, Vol. 6, No. 4, 1999, pp. 259-310.

doi:10.1080/08989629908573933

[3] IFIC, "Review of Monosodium Glutamate, Examining the Myths," 1994.

[4] K. Ikeda, "On the Taste of the Salt of Glutamic Acid," Proceedings of 8th International Congress of Applied Chemistry, Vol. 38, 1917, p. 147.

[5] FDA, "Food and Drug Administration Background for Monosodium Glutamate," 1995.

[6] A. Leung and S. Foster, "Encyclopedia of Common Natural Ingredient Used in Food," Drugs and Cosmetics, New York, Wiley, 1996, pp. 373-375.

[7] D. Biodun and A. Biodun, "A Spice or Poison? Is Monosodium Glutamate Safe for Human Consumption?" National Concord, 4 January 1993, p. 5.

[8] R. S. Geha, A. Beiser, C. Ren, R. Patterson, L. C. Grammar, A. M. Ditto and K. E. Harris,. "Review of Allergic Reaction to Monosodium Glutamate and Outcome of a Multicenter Double Blind Placebo-Controlled Study," Journal of Nutrition, Vol. 130, 2001, pp. 1032S-1038S.

[9] J. U. E. Onakewhor, I. A. O. Oforofuo and S. P. Singh, "Chronic Administration of Monosodium Glutamate Induces Oligozoospermia and Glycogen Accumulation in Wistar Rat Testes," Africa Journal of Reproductive Health, Vol. 2, No. 2, 1998, pp. 190-197.

[10] I. A. O. Oforofuo, J. U. E. Onakewhor and P. E. Idaewor, "The Effect of Chronic Administration of MSG on the Histology of the Adult Wistar Rat Testes," Bioscience Research Communications, Vol. 9, No. 2, 1997.

[11] P. P. Rogers and J. E. Blundell, "Umani and Appetite: Effects of Monosodium Glutamate on Hunger and Food Intake in Human Subjects," Physiology and Behavior, Vol. 486, 1990, pp. 801-804. doi:10.1016/0031-9384(90)90230-2

[12] P. Johnson, "The Assessment of Hepatic Function and Investigation of Jaundice," In: W. Marshall and S. Bangert, (Eds.), Clinical Biochemistry: Metabolic and Clinical Aspects, Churchill Livingstone, New York, 1995, pp. 217-236.

[13] L. Stryer, "Biochemistry," W.H. Freeman and Company, New York, 1995.

[14] A. Guyton and J. Hall, "Textbook of Medical Physiology,” W. B. Saunders Co., Philadelphia, 1996.

[15] W. Ganong, "Review of Medical Physiology," Appleton and Lange, Stamford, 1999.

[16] D. Nelson and M. Cox, "Lehninger Principles of Bioche- mistry," Worth Publishers, New York, 2000.

[17] A. Gowenlock, J. McMurray and D. McLauchlan, "Varley's Practical Clinical Biochemistry," Redwood Burn Ltd., Wiltshire, 1988.

[18] R. Montgomery, T. Conway and A. Spector, "Biochemistry: A Case-Oriented Approach," The C. V. Mosby Company, St. Louis, 1990.

[19] C. Burtis and E. Ashwood, "Tietz Textbook of Clinical Chemistry,” W. B. Saunders Company, London, 1999.

[20] "Merck Manual of Diagnosis and Therapy," Merck and Co., Inc., Rahway, 2004.

[21] M. Kanter, O. Coskun, F. Armutcu, Y. H. Uz and G. Kizilay, "Protective Effects of Vitamin C, Alone or in Combination with Vitamin A, on Endotoxin-Induced Oxidative Renal Tissue Damage in Rats," The Tohoku Journal of Experimental Medicine, Vol. 206, No. 2, 2005, pp. 155-162. doi:10.1620/tjem.206.155

[22] S. Cadenas and A. M. Cadenas, "Fighting the StrangerAntioxidant Protection against Endotoxin Toxicity," Toxicology, Vol. 180, No. 1, 2002, pp. 45-63. doi:10.1016/S0300-483X(02)00381-5

[23] E. M. Bulger and R. V. Maier, "An Argument for Vitamin E Supplementation in the Management of Systemic Inflammatory Response Syndrome," Shock, Vol. 19, 2003, pp. 99-103. doi:10.1097/00024382-200302000-00001

[24] M. Gulec, A. Gurel and F. Armutcu, "Vitamin E Protects against Oxidative Damage Caused by Formaldehyde in the Liver and Plasma of Rats," Molecular and Cellular Biochemistry, Vol. 290, No. 1-2, 2006, pp. 61-67. doi:10.1007/s11010-006-9165-Z

[25] B. I. Ognjanović, S. Z. Pavlović, S. D. Maletić, R. V. Zikić, A. S. Stajn, R. M. Radojicić, Z. S. Saicić and V. M. Petrović, "Protective Influence of Vitamin E on Antioxidant Defense System in the Blood of Rats Treated with Cadmium," Physiological Research, Vol. 52, 2003, pp. $563-570$

[26] A. R. Soylu, N. Aydogdu, U. N. Basaran, S. Altaner, O. Tarcin, N. Gedik, H. Umit, A. Tezel, G. Dokmeci, H Baloglu, M. Ture, K. Kutlu and K. Kaymak, "Antioxidants Vitamin $\mathrm{E}$ and $\mathrm{C}$ Attenuate Hepatic Fibrosis in Biliary-Obstructed Rats," World Journal of Gastroenterology, Vol. 12, No. 14, 2006, pp. 6835-6841.

[27] A. Gurel, O. Coskun, F. Armutcu, M. Kanter and O. A. Ozen, "Vitamin E against Oxidative Damage Caused by Formaldehyde in Frontal Cortex and Hippocampus: Biochemical and Histological Studies," Journal of Chemical Neuroanatomy, Vol. 29, No. 3, 2005, pp. 173-178. doi:10.1016/j.jchemneu.2005.01.001

[28] A. A. Kheir-Eldin, T. K. Motawi, M. Z. Gad and H. M. Abd-ElGawad, "Protective Effect of Vitamin E, $\beta$-Carotene and $N$-Acetylcysteine from the Brain Oxidative Stress Induced in Rats by Lipopolysaccharide," The International Journal of Biochemistry \& Cell Biology, Vol. 33, No. 5, 2001, pp. 475-482. doi:10.1016/S1357-2725(01)00032-2

[29] L. Aldana, V. Tsutsumi, A. Craigmill, M. I. Silveria and E. G. Mejia, "Alpha-Tocopherol Modulates Liver Toxicity 
of Pyrethroid Cypermethrin," Toxicology Letters, Vol. 125, No. 1, 2001, pp. 107-116. doi:10.1016/S0378-4274(01)00427-1

[30] A. Atessahin, S. Yilmaz, I. Karahan, I. Pirincci and B. Tasdemir, "The Effects of Vitamin E and Selenium on Cypermethrin-Induced Oxidative Stress in Rats," Türkish Journal of Veterinary and Animal Sciences, Vol. 29, No. 2, 2005, pp. 385-391.

[31] J. L. Avanzo, C. X. De Mendonca Jr., S. M. Pugine and M. De Cerqueira Cesar, "Effect of Vitamin E and Selenium on Resistance to Oxidative Stress in Chicken Superficial Pectoralis Muscle," Comparative Biochemistry and Physiology Part C: Toxicology \& Pharmacology, Vol. 129, No. 2, 2001, pp. 163-173. doi:10.1016/S1532-0456(01)00197-1

[32] B. Giray, A. Gurbay and F. Hincal, "Cypermethrin-Induced Oxidative Stress in Rat Brain and Liver Is Prevented by Vitamin E or Allopurinol," Toxicology Letters, Vol. 118, No. 3, 2001, pp. 139-146. doi:10.1016/S0378-4274(00)00277-0

[33] M. Kale, N. Rathore, S. John and D. Bhatnagar, "Lipid Peroxidative Damage on Pyrethroid Exposure and Alterations in Antioxidant Status in Rat Erythrocytes: A Possible Involvement of Reactive Oxygen Species," Toxicology Letters, Vol. 105, No. 3, 1999, pp. 197-205. doi:10.1016/S0378-4274(98)00399-3

[34] H. Sies and W. Stahl, "Vitamin E and C, Carotene and Other Carotenoids as Antioxidants," The American Journal of Clinical Nutrition, Vol. 62, 1995, pp. 1315S-1321S.

[35] G. R. Buettner, "The Packing Order of Free Radicals and Antioxidants: Lipid Peroxidation, a-Tocopherol and Ascorbate," Archives of Biochemistry, Vol. 157, 1993, pp. $375-380$

[36] M. K. Sharma and G. R. Buettner, "Interaction of Vitamin $\mathrm{C}$ and Vitamin E during Free Radical Stress in Plasma, An ESR Study," Free Radical Biology \& Medicine, Vol. 14, 1993, pp. 649-653. doi:10.1016/0891-5849(93)90146-L

[37] O. O. Onyema, E. O. Farombi, G. O. Emerole, A. I. Ukoha and G. O. Onyeze, "Effect of Vitamin E on Monosodium Glutamate Induced Hepatoxicity and Oxidative Stress in Rats," Indian Journal of Biochemistry \& Biophysics, Vol. 43, No. 1, 2006, pp. 20-24.

[38] T. Manivasagan and P. Subramanian, "Monosodium Glutamate Affects the Temporal Characteristics of Biochemical Variables in Wistar Rats," Polish Journal of Pharmacology, Vol. 56, No. 1, 2004, pp. 79-84.

[39] C. K. Steven, "Alanine and Aspartate Aminotransferase, Principle and Usage," 3rd Edition, In: J. T. James and R. Jenifer, Eds., Liver Function, in Clinical Chemistry Theory, Analysis and Correlation, M. Mosby, London, 1996, pp. 504-527.

[40] B. T. Doumas, D. Bayse, K. Borner, R. J. Cart, T. Peters and R. Schaffer, "A Candidate Reference Method for the Determination of Total Protein in Serum: Development and Validation," Clinical Chemistry, Vol. 27, No. 10, 1981, pp. 1642-1650.
[41] J. E. C. Gustafsson, "Improved Specificity of Serum Albumin Determination and Estimation of Acute Phase Reactant by the Use of Bromocresol Green Reaction," Clinical Chemistry, Vol. 22, No. 5, 1976, pp. 616-622.

[42] D. A. Adekomi, "Madagascar Periwinkle (Catharanthus roseus) Enhances Kidney and Liver Functions in Wistar Rats," International Journal of Biomedical and Health Sciences, Vol. 6, No. 4, 2010, pp. 245-254.

[43] H. T. Bergen, T. M. Mizuno and J. Taylor, "Hyperphagia and Weight Gain after Gold-Thioglucose and Monosodium Glutamate: Relation to Hypothalamic Neuropeptide," Endocrinology, Vol. 139, No. 11, 1998, pp. 4483-4488. doi:10.1210/en.139.11.4483

[44] S. Mozes, Z. Sefcikova, L. Lenharde and L. Raeek, "Obesity and Changes of Alkaline Phosphatase Activity in the Small Intestine of 40-80-Day Old Subjects to Early Postnatal Overfeeding of Monosodium Glutamate," Physiological Research, Vol. 53, 2004, pp. 177-186.

[45] Y. S. Diniz, A. A. Fernando, K. E. Campos, F. Mani, B. D. Ribas and E. L. Novelli, "Toxicity of Hyper Caloric Diet and Monosodium Glutamate: Oxidative Stress and Metabolic Shifting in Hepatic Tissue," Food and Chemical Toxicology, Vol. 42, 2004, pp. 319-325. doi:10.1016/j.fct.2003.09.006

[46] R. Walker and J. R. Lupien, "The Safety Evaluation of Monosodium Glutamate," Journal of Nutrition, Vol. 130, Suppl. 4, 2000, pp. 1049-1052S.

[47] J. S. Park, M. A. Choi, B. S. Kim, I.S. Han, T. Kurata and R. Yu, "Capsaicin Protects against Ethanol-Induced Oxidative Injury in the Gastric Mucosa of Rats," Life Science, Vol. 67, 2000, pp. 3087-3093. doi:10.1016/S0024-3205(00)00890-0

[48] M. Al-Mamary, M. Al-Habori, A. M. Al-Aghbari and M. M. Baker, "Investigation into the Toxicological Effects of Catha Edulis Leaves: A Short-Term Study in Animals," Phytoetherapy Research, Vol. 16, 2002, pp. 127-132. doi:10.1002/ptr.835

[49] G. Poli, E. Albano and M. U. Dianzani, "Lipid Peroxidation and Covalent Binding in the Early Function Impairment of Golgi Apparatus by Carbon Tetrachloride," Vol. 8, No. 1, 1990, pp. 1-10.

[50] E. O. Farombi and O. O. Onyema, "Monosodium Glutamate Induced Oxidative Damage and Genotoxicity in Rat: Modulatory Role of Vitamin C, Vitamin E and Quercetin," Human and Experimental Toxicology, Vol. 25, 2006, pp. 251-259. doi:10.1191/0960327106ht621oa

[51] R. T. Chung, D. R. Casson, G. Murray, S. Song, S. Grinspoon and C. Hadigan, "Alanine Aminotransferase Levels Predict Insulin Resistance in HIV Lipodystrophy," Journal of Acquired Immune Deficiency Syndromes, Vol. 34 No. 5, 2003, pp. 534-536. doi:10.1097/00126334-200312150-00015

[52] S. M. Grundy, "Hypertriaglyceridemia, Insulin Resistance, and the Metabolic Syndrome," American Journal Cardiology, Vol. 83, No. 9, 1999, pp. 25F-29F. doi:10.1016/S0002-9149(99)00211-8

[53] S. M. Haffner, "Management of Dyslipidemia in Adults 
with Diabetes (American Diabetes Association Position Statement)," Diabetes Care, Vol. 21, 1998, pp. 160-178. doi:10.2337/diacare.21.1.160

[54] P. W. Wilson, W. B. Kannel, H. Silbershatz and R. B. D'Agostino, "Clustering of Metabolic Factors and Coronary Artery Disease," Archives of Internal Medicine, Vol. 159, No. 10, 1999, pp. 1104-1109. doi:10.1001/archinte.159.10.1104

[55] B. Naganna, "Plasma Proteins," In: G. P. Talwar, L. M. Srivastava and K. D. Moudgil, Eds., Textbook of Biochemistry and Human Biology, 2nd Edition, Prentice Hall of India Private Ltd., New-Delhi, 1989, pp. 59-61.

[56] N. W. Tiez, "Fundmental of Clinical Chimestry," WB Saunder Co., Philadelphia, 1986, p. 723.

[57] W. J. Johnson, W. W. Hagge, R. D. Wagoner, R. P. Dinapoli and J. W. Rosevear, "Effects of Urea Loading in Patients with Far-Advanced Renal Failure," Mayo Clinic Proceedings, Vol. 47, No. 1, 1972, pp. 21-29.
[58] F. L. Mitchell, N. Veall and R. W. E. Watts, "Renal Function Tests Suitable for Clinical Practice," Annals of Clinical Biochemistry, Vol. 9, 1972, pp. 1-20.

[59] J. F. Zilva, P. R. Panmall and P. D. Mayne, "Clinical Chemistry in Diagnosis and Treatment," 5th Edition, England Clays Ltd., St. Ives Plc., 1991.

[60] N. A. Vinodini, A. K. Nayanatara, C. Ramaswamy, V. R. Anu, D. K. Rekha, G. K. M. Damadara, B. Ahamed and R. B. Shabarinath, "Study on Evaluation of Monosodium Glutamate Induced Oxidative Damage on Renal Tissue on Adult Wistar Rats," Journal of Chinese Clinical Medicine, Vol. 5, No. 3, 2010, pp. 144-147.

[61] E. O. Farombi, "Monosodium Glutamate-Induced Oxidative Damage and Genotoxicity in the Rat: Modulatory Role of Vitamin C, Vitamin E and Quercetin," Human \& Experimental Toxicology, Vol. 25, No. 5, 2006, pp. 251259. doi:10.1191/0960327106ht621oa 